Uysal, B. ve Atmaca, Ç. (2016). Üniversite sloganlarının bağdaşıklık açısından incelenmesi. Ana Dili Eğitimi Dergisi, $4(4), 607-624$.

\begin{tabular}{c}
$\begin{array}{c}\text { Ana Dili Eğitimi Dergisi } \\
\text { Journal of Mother Tongue Education } \\
\text { www.anadiliegitimi.com }\end{array}$ \\
Geliş/Received: $02.09 .2016 \quad$ Kabul/Accepted: 18.10 .2016 \\
\hline
\end{tabular}

\title{
Üniversite Sloganlarının Bağdaşıklık Açısından İncelenmesi
}

\begin{abstract}
Başak UYSAL*
Çă̆la ATMACA**

Öz

Bu çalışmada, Türkiye'de yer alan devlet ve vakıf üniversitelerinin sloganları, metin biliminin bileşenlerinden olan bağdaşıklık ekseninde incelenmiştir. Çalışma kapsamına Yüksek Öğretim Kurulu (YÖK) tarafından resmî olarak tanınan 193 üniversite alınmış, bu üniversitelerin sloganları bağdaşıklık ögeleri ekseninde analiz edilmiştir. Nitel araştırma yöntemlerinden söylem çözümlemesinin temel alındığı çalışmada elde edilen sonuçların başlıcaları şunlardır: 193 üniversiteden 102 üniversitenin İnternet sayfalarında kalıcı bir slogana yer verdiği, 91 üniversitenin ise yer vermediği görülmektedir. Bağdaşıklık unsurları dikkate alındığında sloganların büyük çoğunluğu, cümle yerine kelime grubundan oluşmaktadır. Kelime grupları içerisinde en çok tercih edileni, sıfat ve sıfat fiil grupları olmuştur. Söylem analizinin en önemli sonuçlardan birisi, üniversite sloganlarının yer verdiği temaların başlıcalarının gelecek ve bilimsellik olmasıdır. Çalışma sonucunda elde edilen bulgu ve yorumların dilbilimi ve söylem çözümlemesi alanında çalışan araştırmacılara ışık tutacağı düşünülmektedir.
\end{abstract}

Anahtar Sözcükler: Bağdaşıklık, slogan, üniversite sloganları, söylem çözümlemesi.

\section{Analysing Cohesion in University Slogans}

\begin{abstract}
This study aims to analyze the cohesion elements of discourse analysis found in the slogans of state and private universities in Turkey. 193 universities which were included in the formal website of Higher Education Council (YÖK) and the slogans of these universities were analyzed in terms of cohesion. Discourse analysis that is one of the qualitative data analysis methods was used and some of the main findings of the research results are as follows: out of 193 universities 102 universities possess a slogan in their websites but 91 universities do not. As for cohesion high majority of the slogans consist of group of words instead of sentences. Adjective clauses and adjective-verbal clauses were found to be among the most preferred ones. One of the most important results of discourse analysis is that the themes of the university slogans centered around future and science. The research findings are thought to shed light on important topics studied in linguistics and discourse analysis, and guide future researchers.
\end{abstract}

Keywords: Cohesion, slogan, university slogans, discourse analysis.

\footnotetext{
* Öğr. Gör. Dr., Gazi Üniversitesi, Gazi Eğitim Fakültesi, Sosyal Bilimler ve Türkçe Eğitimi Bölümü, Türkçe Öğretmenliği Ana Bilim Dalı, Ankara, basakuysal@gazi.edu.tr

**Arş. Gör. Dr., Pamukkale Üniversitesi, Eğitim Fakültesi, Yabancı Diller Eğitimi Bölümü, İngiliz Dili Eğitimi A.B.D., Denizli/Türkiye, caglaatmaca90@gmail.com
} 


\section{Giriş}

Milattan önce IV. yüzyılda Platon'un akademinin kapısına "Geometri bilmeyen giremez." yazdırdığı söylencesi, geçerliliğini milattan sonra XXI. yüzyılda hâlâ devam ettirmektedir. İlk üniversite sloganı olarak kabul edilebilecek bu ifadenin işaret ettiği nokta, üniversitenin talep edilen ve koşul belirleyici bir kurum olduğudur. Türk-İslam kültürve eğitim tarihinde anılan Yunus Emre'nin dergâhtaki pirine sarf ettiği "Eğri odun (bile) giremez." ve Mevleviliğin "Gel! Ne olursan ol yine gel!" söylemi, kurum ve kuruluşların kolektif bellekte sloganla hatırda kaldığını göstermektedir.

Bir söylem ve bir metin türü olarak slogan, Sosyal Bilimler Sözlüğünde "Bir düşünceyi kolay hatırlanıp tekrarlanabilir bir biçimde ifade eden kısa ve kolay cümle." olarak tanımlanmaktadır (Demir ve Acar, 2005: 369). Scheffler (1961), sloganlarıana fikirleri temsil eden sembollerin bir araya gelmesi şeklinde tanımlamış, sloganların anlamlarının esasen belirsiz olduğunu ve bakış açısına göre uyumsuz iddiaları ve yorumları ifade edebileceğini de eklemiştir. Bir diğer bakış açısına göre sloganlar, bir marka hakkında açıklayıcı ya da ikna edici bilgileri ileten kısa ifadeler olarak tanımlanır (Supphellen ve Nygaardsvik, 2000; Lehto, Lee ve İsmail, 2012: 250). Marka adı ve slogan, uluslararası pazarda yer edinmeye çalışan firmaların rakiplerinden sıyrılarak kendi farklarını ortaya koymak ve hedef kitledeki tüketicilerle daha rahat iletişim kurabilmek için kullandıkları araçlar olarak görülmektedir. Bu iki araçta yerel kültürün ve dilin izlerine rastlamak mümkündür (Kantar, 2014: 71-78). Tüm tanımların uzlaştığı nokta, sloganın ana fikri yansıtan, kısa ve akılda kalıcı ifadeler olduğudur. Literatür ve uygulamalardan hareketle söylemek mümkündür ki slogan, kimi zaman bir yaşanmışılı sonucu kendiliğinden oluşsa da ait olduğu kurumun kısaltılmış ve akılda kalıcı bir özeti niteliğindedir.

Sloganlar, amaçları birbirinden oldukça bağımsız olan kuruluşlarda dahi kullanılabilmektedir. Sloganların destek sağlamak amacıyla işe koşulmasının kurumlar için ortak bir yöntem olduğu düşünülmektedir (Wangenge-Ouma ve Langa, 2010). Sloganların sıklıkla kullanıldığı disiplinlerden birisi, pazarlama disiplini ve reklam söylemidir. Reklamlarda birbiri ardına ritmik kullanımlar, tekrarlar, şarkılar, etkili görüntüler, dil oyunları ve sloganlar kullanılır (Özyıldırım, 2010:162). Alıcı açısından düşünüldüğünde her reklam, potansiyel tüketici konumunda bulunan ve hedef kitle olarak seçilen bir grup insanı etkilemek amacıyla özel olarak planlanmaktadır (Özyıldırım, 2010: 163). Dolayısıyla sloganlar, doğrudan hedef kitle için hazırlanmaktadırlar.

Üniversite sayısının ve seçeneklerin in de artmasıyla üniversite, artık Platon'un akademisinde olduğu varsayılan slogandaki gibi sadece koşul belirleyici bir kurum değildir. Üniversiteler, tıpkı reklam söylemlerinde olduğu gibi, davetkâr ve seçilebilir görünme amacıyla kurum kimliği göstergelerinden biri olan sloganları kullanmaktadır. Greenwood ve Levin (2000), üniversitelerin yaşadığı bu değişimle ilgili olarak şunları söylemektedir: “Üniversiteler, kâr amaçlı girişimci birimleriyle ve esas olarak sosyal 
misyonlarla değil de üniversitenin ekonomik çıkarlarıyla ilgilenen idareleri ve mütevelli heyetleriyle, özel sektörün tipik birer hizmet şirketi hâline gelmektedir." Kurum kimliğinin bileşenlerinin misyon, vizyon, amblem (logo) ve slogan olduğu göz önüne alındığında üniversitelerin kullandıkları sloganların talep eden kitle bakımından ayırıcı özellik olduğu düşünülmektedir. Bir metin olarak sloganlar, metin bilimin temel bileşenlerinden olan bağdaşıklık ve tutarlılık unsurlarını sağladığı takdirde duygusal ve zihinsel etki yapabilmektedir.

\section{Bağdaşıklık ve tutarlıık}

Bamberg (1983: 418), bağdaşıklığı “Metni aşan ve söylemin daha büyük öbekleriyle birbirine bağlanan dilbilimsel bir sistem." olarak tanımlamıştır. Richard, Platt ve Weber (1985: 45) bağdaşıklı̆ı̆n bir metnin farklı elementleri arasındaki dil bilgisel ve/veya sözcükler arası ilişkilere dayandığını ifade etmiştir. Günay (2003: 57) bağdaşıklığı küçük, tutarlıı̆ı ise büyük yapı unsurları içerisinde değerlendirerek bağdaşıklığı bir yazının metin olmasını sağlayan, metin içi ilişkileri kuran dille ilgili özelliklerin tümü olarak tanımlar. Tanımlardan hareketle bağdaşıkık; ek, sözcük türü, sözcük yapısı, sözcük grupları, cümle türleri ve dizilimleri gibi dil bilgisi çatısı altında yer alan unsurların ve yazım/noktalama bileşenlerinin küçük yapıdan büyük yapıya geçişini sağlayan aracılar olarak görev almasıdır.

Tutarlılık; bir metnin yüzeysel bağlara dayalı olmayan fakat belirli bir söylemin tematik gelişiminden, bilgi organizasyonundan ya da iletişimsel amacından türeyen elementleri arasındaki ilişkiler türü olarak tanımlanmaktadır (Kuo, 1995: 54). Bander (1983: 6) tutarlılığı tanımlarken daha çok bir metnin ana fikirlerinin nasıl yapılandırıldığının ve fikirlerin belirli bir sırada birbirleriyle açıkça ilişkili olup olmadığının önemli olduğunu belirtmiştir. Hobbs (1979:1) tutarlılı̆ı cümlecikler arası ilişkiler olarak tanımlamıştır ve tutarlılık ilişkilerinde okurların bilişsel metin gösterimindeki bağlantılılığı göz önüne aldığını ileri sürmüştür. Coşkun (2005: 9)'a göre ise tutarllık, metin içindeki anlamsal ve mantıksal bağlantılarla oluşan konu akışındaki bütünlüktür.

Yorum ve yeni bilginin arasındaki ilişkiyle ilgili olarak Widdowson (1983) bağdaşık olup da tutarlı olmayan metinlerin olabileceğini belirtmiştir. Bağdaşıklık ve tutarlıı̆ın birbirlerinin ön tamamlayıcısı olmadığına dair bir diğer açıklama, Halliday ve Hasan (1976)'a aittir. Halliday ve Hasan (1976: 18-28)' a göre tutarılık, ilgili durumun metin ve bağlam içerisindeki bağdaşıklığına bağlıdır. Metin içerisindeki bağdaşıklık ise dildeki cümleler arası ilişkiler ile ilgilidir ki bu ilişkiler, yazarın sözdizimsel ve anlamsal seçimi ile gerçekleştirilir. Bu durum, yazarın okuyucuya göre durumsal ve anlamsal bakımdan tutarlı olan ama cümleler arası bağdaşıklığı olmayan bir metin oluşturabileceğine işaret etmektedir. Yazar, ayrıca durum ve konu olarak anlam sürekliliği olmayan bağdaşık bir metin oluşturabilir. 
Bir metni tutarlıı̆̆ı bakımından incelemek, üst yapı olarak genel metin çerçevesinde, metnin tümünü anlamsal olarak değerlendirmek demektir. Bağdaşıklık, metnin dil bilgisel yanıyla ilgiliyken, tutarlıık kabul edilebilirlik durumu ile ilintilidir. Metnin tutarlı olması, ögelerin çizgisel gelişimi içinde izlek, kişi, yer ya da olay bakımından yinelenmesi ve temel bir izlek çerçevesinde gelişmesi gerekmektedir (Günay, 2003: 100).

Bağdaşıklık ve tutarlıık bir arada yahut ayrı ayrı düşünüldüğünde bu konudayer etmiş önemli çalışmaların varlığına rastlamak mümkündür. Johnson (1992), ana dili İngilizce ve Malayca olanların ve de İngilizceyi ikinci dil olarak kullanan Malezyalıların yazdığı kompozisyonları, bağdaşıklık ve tutarlılık bakımından karşılaştırmıştır. Çalışma sonucunda katılımcılar tarafından yazılan kompozisyonlar arasında bağdaşıklık miktarı açısından farklııılar olmadığı tespit edilmiştir. Ayrıca, Malaya dilinde yazılan iyi kompozisyonların zayıf kompozisyonlara oranla daha çok cümleler arası anlamsal bağlara sahip olduğu görülmüştür. Ancak ana dili İngilizce olanlar tarafından İngilizce yazıımış iyi kompozisyonların zayıf kompozisyonlara oranla daha çok cümleler arası anlamsal bağlara sahip olduğu saptanmıştır.

Kuo (1995), bağdaşıklık ve tutarlılı̆ı akademik metnin seviyesinde incelemiş ve bileşenlerini sözcük, cümle yapısı ve bilgi organizasyonu olarak belirlemiştir. Çalışması sonucunda metnin tematik gelişimi için işlevsel olarak daha önemli olan cümlelerin genellikle diğer cümlelerle daha çok bağdaşıklık bağlarına sahip olduğu sonucuna ulaşmıştır. Cümle düzeyinde bulduğu bir diğer sonuç, dil bilgisi bağlamında aynı özelliklere sahip olan cümlelerin birbirinden bağımsız metinlerde farklı iletişimsel değerler taşıyabileceğidir.

Palmer (1999) tarafından yapılan bir araştırmada İngilizce dersindeki öğrencilerin yazılı bir ödevi tamamlamak için bağdaşıklık ve tutarlıık unsurlarını kullanma şekilleri gözlenmiş ve sözcük düzeyinde bağdaşıklık özellikleri olarak yineleme, eş anlamlı sözcük ve alt kavramlaştırma kullanımının öğrencilerin yazma becerisinin genel olarak kalitesini değiştirebileceği sonucuna varılmıştır.

Metin düzeyinde bağdaşıklık unsurları üzerine yapılan çeşitli araştırmalar mevcuttur. Coşkun (2005), ilköğretim 5. ve 8. sınıfta okuyan toplam 372 öğrencinin öyküleyici anlatımlarındaki bağdaşıklık ve tutarlılık unsurlarını incelemiş ve bağdaşıklıkla ilgili olarak öğrencilerin yazdıkları hikâyelerde eksiltili anlatım, bağlama ögeleri, kelime bağdaşıklığı, gönderim ve değiştirim ögelerini kullandığını belirlemiştir. Tutarlılık ögesinde ise öğrencilerin tutarlılık puanı 5 puan üzerinden 3,1 olarak hesaplanmıştır ve öğrencilerin daha önce söylenmesi gereken bilgiyi sağlama, olaylar arası ilişkileri metne aktarma, olay akışı, odak noktası, olay örgüsü ve metin türü gibi hususlarda sorun yaşadığı bulunmuştur. 
Özyıldırım (2010), Türkçedeki farklı metin türlerinin söylem özelliklerini belirlemeyi amaçlamış ve metin türleri içerisine reklam metinlerini de katarak sloganlara değinmiştir. Çalışma sonucunda reklamların izleyiciye reklamı yapılan ürünle ilgili etkili ve akılda kalııı bilgiler vererek onları etkileme ve özendirme yoluyla ikna etme ve bir tüketim ortamı yaratma gibi ikili bir işlevi olduğu sonucuna ulaşıımıştır. Özyıldırım (2010)'a göre TV reklamlarının hem etkileşimsel hem de bilgi verici özellikler gösteren, bazı öyküsel özellikler gösterse de temel olarak öyküsel olmayan, ağırlıklı olarak belirgin gönderimlerden oluşan, kendi içerisinde ikna edici söylem özelliklerine çok fazla sahip olmasa da bütünce içerisindeki türlerin çoğundan daha çok ikna edici özellik içeren, büyük ölçüde somut, canlı, hareketli ve resmî olmayan sözlü bir tür olduğunu söylemek mümkündür.

Yılmaz (2012), 11. sınıf öğrencilerinin öyküleyici anlatımlarındaki bağdaşıklık ve tutarlıık unsurlarını çeşitli sosyodemografik özellikler açısında incelemiştir. Öğrencilerin kullandığı bağdaşıklık araçlarının kullanım ortalaması sırası ise bağlama ögeleri $(13,24)$, gönderim $(11,67)$, eksiltili anlatım $(5,69)$ ve değiştirim $(1,69)$ şeklindedir. Demografik özelliklerden okul türü, cinsiyet, öğrencinin okuduğu kitap sayısı, sosyal medyada yazışma süresi değişkenleri ile bağdaşıklık arasında anlamlı farkılık görülürken ailenin gelir düzeyinin bağdaşıklık üzerinde herhangi anlamlı farklılık oluşturmadığı bulunmuştur. Tutarlılık unsurunda ise ilgili tüm sosyodemografik özellikler ile öğrencilerin paragraflarında tutarılık oluşturma başarıları arasında anlamlı farklııkların olduğu sonucuna varılmıştır.

İlköğretim öğrencileri ile yapılan bağdaşıklık ve tutarlıık çalışmalarından biri de Çoban (2012)’a aittir. Çoban (2012); üst, orta ve alt olmak üzere 3 farklı grupta yer alan okullardaki 7. sınıf öğrencilerinin metinlerindeki bağdaşıklık ve tutarlılık unsurlarını sosyodemografik özellikleri açısından incelemiştir. Çalışma sonucunda gönderim, değiştirim, eksilti ve kelime bağdaşıklığı açısından katılımcı gruplar arasında istatistiksel anlamda farklılık olduğu saptanmıştır. Fakat tutarlılık unsurunda gruplar arası sosyodemografik özellikler açısından istatistiksel anlamda herhangi anlamlı farklılığa rastlanmamıştır.

Paragraf düzeyinde bağdaşıklık ve tutarlılık alanındaki bir diğer çalışma, Can (2012) tarafından yapılmıştır. Çalışma sonucunda katılımcıların şahıs zamiri, işaret zamiri, işaret sıfatı, özne kullanımı, gönderim ögesi, eş anlamlı kelimleler ve uygun kelime kullanımı konularında sorun yaşadıkları tespit edilmiştir. Çalışmada katılımcıların tutarlııkla da ilgili sorunlar yaşadığı belirlenmiştir. Tutarlııkla ilgili sorunların paragrafa giriş, paragrafı sonlandırma, düşünce organizasyonu, yardımcı fikir ve paragraf bölümlerinin oluşturulması unsurlarında yoğunlaştığı belirlenmiştir. 
Gonzales ve Pacheco (2012), bölgesel bir üniversite olan Border Üniversitesinin ulusal olarak tanınmış bir üniversiteye dönüşümünü açıklamak adına üniversitenin kullandığı sloganları incelemişlerdir.

Uysal ve Kayman (2014) tarafından yapılan çalışmada üniversite öğrencilerinin "Gazili olmak ayrıcalıktır." sloganına yönelik algılarını tespit etmek amacıyla sosyal paylaşım siteleri ve forumlarda yer alan, "Gazili olmak ayrıcalıktır." sloganını içeren paylaşımları incelenmiş, çalışma sonucunda üniversite öğrencilerinin ilk sınıflarda slogana yönelik görüşlerinin anlamlı fark yaratacak biçimde yüksek olduğu, 2. ve 3. sınıflarda bu algının kısmen olumsuzlaştığı tespit edilmiştir. Son sınıfta ise olumlu ve olumsuz algının yakınlaştığı dikkat çekmektedir. Mezun durumda olanlarda ise büyük çoğunluk, "Gazili olmak ayrıcalıktır." sloganını olumlu olarak yorumlamaktadır. Öğrencilerin sloganın vaad ettiği beklentiyi ilk sınıflarda sabit tuttukları, ilerleyen sınıflarda bu beklentinin altını doldurmaya çalıştıkları hâlde olumlu veriler bulamadıkları, mezunların ise vaadin karşılı̆ııı uygulama alanında gördüklerini tespit etmek mümkündür.

Kantar (2014), Türkiye ve Orta Doğu'da yer alan çok uluslu şirketlerin marka adı ve slogan tercihlerini mercek altına almış ve ilgili marka adları ve sloganları literatürde var olan standardizasyon derecelerine göre sınıflandırmıştır. Elde edilen verilerden hareketle Türkiye'deki marka adlarının büyük çoğunluğunun standardize edildiği Orta Doğu'daki marka adlarının ise çoğunlukla yerelleştirildiği sonucuna varılmıştır. Marka sloganlarında ise Türkiye' de uyarlama oranları yüksek bulunurken Orta Doğu'da bu oranın standardizasyon oranından daha düşük olduğu bulunmuştur.

Ersoy (2014), 1980 yılı öncesinde ve sonrasında gazetelerdeki reklam amaçlı sloganları incelemiş ve 1980 yılı öncesindeki sloganların ürün odaklı olduğu ve rasyonel vaatlerde bulunduğu görülürken 1980 sonrası reklamların duygusal yönünün ağır bastığı ve duygusal vaatlerde bulunduğu sonucuna ulaşmıştır.

Arslan (2014), reklam sloganlarının ve popüler dilin üniversite öğrencileri tarafından ne oranda kullandıklarını saptamak amacıyla üniversite öğrencilerine yönelik bir anket hazırlamış ve bu anketi 350 öğrenciye uygulamıştır. Araştırmada kız ve erkek öğrencilerin reklamlara ve reklamlarla birlikte inşa edilen dile büyük oranda aşina oldukları tespit edilmiş, ancak reklam sloganlarını çevrelerinde duyma ve bizzat kullanma oranlarının bu kadaryüksek olmadığı görülmüştür. Araştırmacı, bu sonucu gençlerin reklamların popüler dili ile aralarına mesafe koyma çabası ve sloganlara yönelik tutum geliştirememeleri şeklinde yorumlamıştır.

İlgili araştırmalardan hareketle slogan kavramı üzerinde kavramın farklı boyutlarını kapsayan çalışmaların gerçekleştirildiğini söylemek mümkündür. Bununla birlikte üniversite sloganlarına yönelik çalışmalar, sınırlı düzeydedir. Türkiye'deki üniversitelerin sloganlarına yönelik çalışmalar göz önüne 
alındığında bu sınırılık daha da kesin çizgilere sahip olmaktadır. Çalışmayı önceki çalışmalardan ayıran en önemli özelliği, Türkiye'deki üniversitelerin sloganlarının hem bağdaşıklık hem tutarlıık açısından incelenmesidir.

İlgili çalışmaların birleşme noktasının "metin" olduğu dikkate alınarak, bu çalışmada kurumsal kimlikte belirleyici bir yeri olan sloganların üniversite bağlamında kullanılış biçimleri, bağdaşıklık ve tutarlılık ekseninde ele alınmıştır. Bu bağlamda araştırma, şu soruları cevaplamayı amaçlamaktadır:

1- Türkiye'de yer alan devlet ve vakıf üniversitelerinin sloganlarındaki bağdaşıklık unsurları nelerdir?

2- Türkiye' de yer alan devlet ve vakıf üniversitelerinin sloganlarındaki tutarlılık unsurlarınelerdir?

\section{Yöntem}

Bu çalışma, Türkiye' de yer alan devlet ve vakıf üniversitelerinin sloganlarını bağdaşıklık ve tutarlıık açısından incelemeyi amaçlamaktadır. Metinlerde aranan bağdaşıklık unsurları, söz dizimi ve cümle özellikleri ile tutarlıık unsurları ise tema ve ana fikir ile sınırlandırılmıştır. Çalışmada ilgili sloganların yazılış özelliklerine herhangi müdahalede bulunulmamıştır. Sloganlarda kullanılan yazı özellikleri olduğu gibi verilmiştir. Sadece dergi yayın ilkeleri doğrultusunda tüm metinde aynı yazı tipi kullanılmıştır.

Çalışmada Yüksek Öğretim Kurulu (YÖK) tarafından tanınan üniversitelerin İnternet sayfalarında bulunan sloganları bağdaşıklık ve tutarlıık unsurlarına göre incelendiğinden betimleyici araştırma modeli kullanılmıştır. Çalışma evrenini oluşturan Türkiye'deki 193 üniversitenin tümü araştırmaya dâhil edilmiştir ve ilgili üniversitelerden slogana sahip olanların slogan metinleri üzerinde söylem çözümlemesi yapılmıştır. Araştırmada yer alan nitel veri nedeniyle nitel veri analizi yapılmış ancak nitel veri analizi sonuçları nicelleştirilerek rakamların ve sözlerin birbirlerini tamamlamaları sağlanmıştır. Yazarlar, öncelikle bağdaşıklık ve tutarlılık unsurlarının hangilerinin kullanacağı konusunda ortaklaşa karara varmış, daha sonra bu belirlenen şablon üzerinden var olan veriyi kategorilere ayırıp yorumlamışlardır. Öncelikle her bir kodlayıcı, eldeki veriyi ilgili unsurlara göre kendi başına kodlamış ve kodlama işlemini tamamladıktan 3 hafta sonra oluşturulan kodlara tekrar bakmıştır. Bu süre, kodlayııının kendi iç güvenirliğini sağlamak amacıyla yapılmıştır. Kodlayııılar arası güvenirliği sağlamak için verinin \%25'inin analizinin tamamlanmasından sonra kodlayıcılar bir araya gelmiş ve oluşturdukları kodları karşılaştırmışlardır. İlk yapılan toplantıda kodlayııılar arası güvenirlik, Miles ve Huberman (1994: 64) formülüne göre \%80 olarak bulunmuştur (Bk. Şekil 1).

Şekil 1. Kodlayıcılar arası güvenirlik (Miles ve Huberman, 1994)

\begin{tabular}{|l|l|}
\hline Kodlayıcılar arası güvenirlik $=$ & görüş birliği \\
görüş birliği+görüş ayrılığı & $\times 100$ \\
\hline
\end{tabular}


Illk görüşmede kodlayıcıların akıllarındaki sorular tartışılarak giderilmiş ve değerlendirme kriterlerine daha çok açıklık getirilmiştir. Verinin tamamının incelenmesinden sonra kodlayıcılar tekrar bir araya gelmiş ve oluşturdukları kodların güvenirliği yine Miles ve Huberman (1994: 64) formülüne göre \%90 olarak bulunmuştur. Veri kodlama ile ilgili herhangi görüş ayrılığı olmayana değin araştırmacılar, kodlayıcı sıfatıyla toplantı yapmış ve farklı yorumlanabilecek bazı sloganlar üzerinde tam görüş birliği sağlanmıştır.

Nitel verinin analiz edilmesinde Glaser ve Strauss (1980) tarafından önerilen gömülü teoride bulunan sürekli karşılaştırma yöntemi kullanıımıştır. Ancak gereksiz veri ile uğraşmamak ve çalışmaya alt yapı oluşturmak amacı ile öncelikle ilgili çalışmalar taranmış ve daha sonra veri analizine geçilmiştir. Bu yönüyle çalışmanın Thornberg (2012)'in önerdiği bilgilendirilmiş gömülü teoriye dayalı olduğunu söylemek daha doğru olacaktır. Bu sayede kodlayıcılar zikzak çizerek yani veriyi sürekli bir önceki ve bir sonraki veri ile karşılaştırarak ana ve alt kategorileri oluşturmuşlardır (Dörnyei, 2007). Elde edilen nitel analizlerin daha iyi anlaşılması adına nitel veri nicelleştirilmiş, kelimelerle ilgili olan veri, rakamlara dönüştürülmüştür. Araştırmada yüzde ve frekansları gösteren grafik kullanımının sebebi budur. Amaç, bir anlamda niteli nicelleştirmek ve niceli nitelendirmektir. Nicel ve nitel yöntemlerin kullanımı araştırma konusunun daha derinlemesine sorgulanmasını ve anlaşımasını sağlayacaktır (Cresswell, Plano Clark, Gutmann ve Hanson, 2003). Böylelikle, rakamlar ve kelimeler birbirlerini anlamlı ve uyumlu bir şekilde tamamlayacaklardır ve okuyucu metin içi grafiklerin ne anlama geldiğini daha hızlı kavrayabilme imkânına sahip olacaktır.

\section{Çalışma dokümanı özellikleri}

Çalışma kapsamında ele alınan 193 üniversiteden 107 tanesi devlet, 86 tanesi vakıf üniversitesidir. ${ }^{+}$Üniversitelerin kuruluş yıllarına dair bilgiler, Grafik 1'de verilmiştir.

\footnotetext{
† Çalşmanın gerçekleştirildiği tarihte 23.07.2016 tarihinde yayımlanan 15 üniversitenin kapatılmasına dair KHK gündemde olmadığı için, söz konusu 15 vakıf üniversitesine ait sloganlar da çalışmaya dâhil edilmiş̧tir.
} 
Grafik 1. Üniversitelerin kuruluş yıllarına göre dağııımı

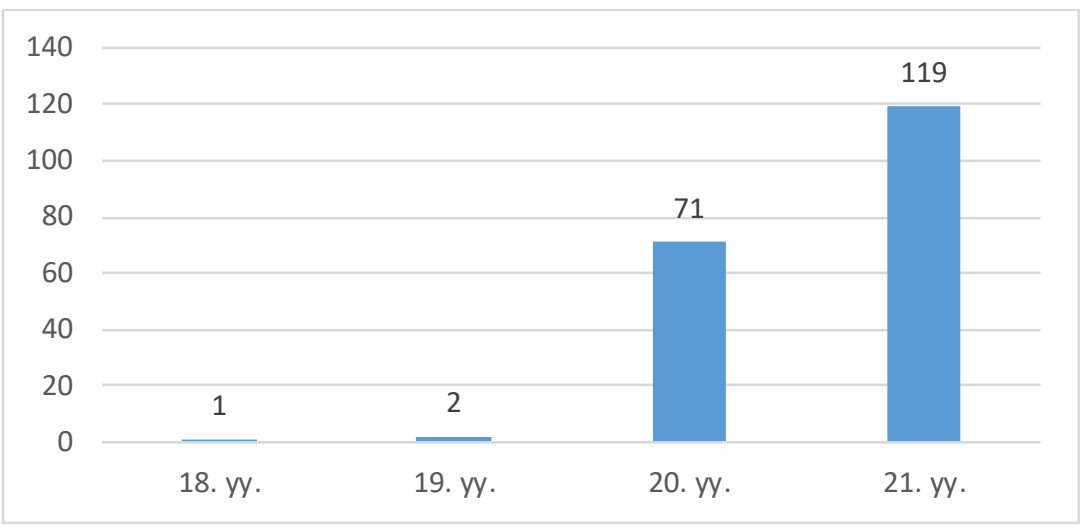

Üniversitelerin kuruluş yılları dikkate alındığında 3 kurumun 1933 yılında gerçekleşen "Üniversite Reformu” öncesi kurulan eğitim kurumlarının kuruluş tarihini kendilerine temel aldığı görülmektedir. 71 üniversite, 20. yüzyılda kurulurken 119 üniversite, 21. yüzyılda kurulmuştur. Bu durum göstermektedir ki çalışma sonunda ulaşılan slogan algısında belirleyici olan, 21. yüzyıl üniversiteleridir. Çalışma kapsamında ele alınan 193 üniversitenin İnternet sitelerindeki logo ile birlikte sunulan veya resmî tanıtım videolarında yer alan bir sloganları sahip olup olmadığına dair veriler, Grafik 2'de sunulmuştur (Bk. Grafik 2).

Grafik 2. Devlet ve vakıf üniversitelerinin slogan kullanma durumları

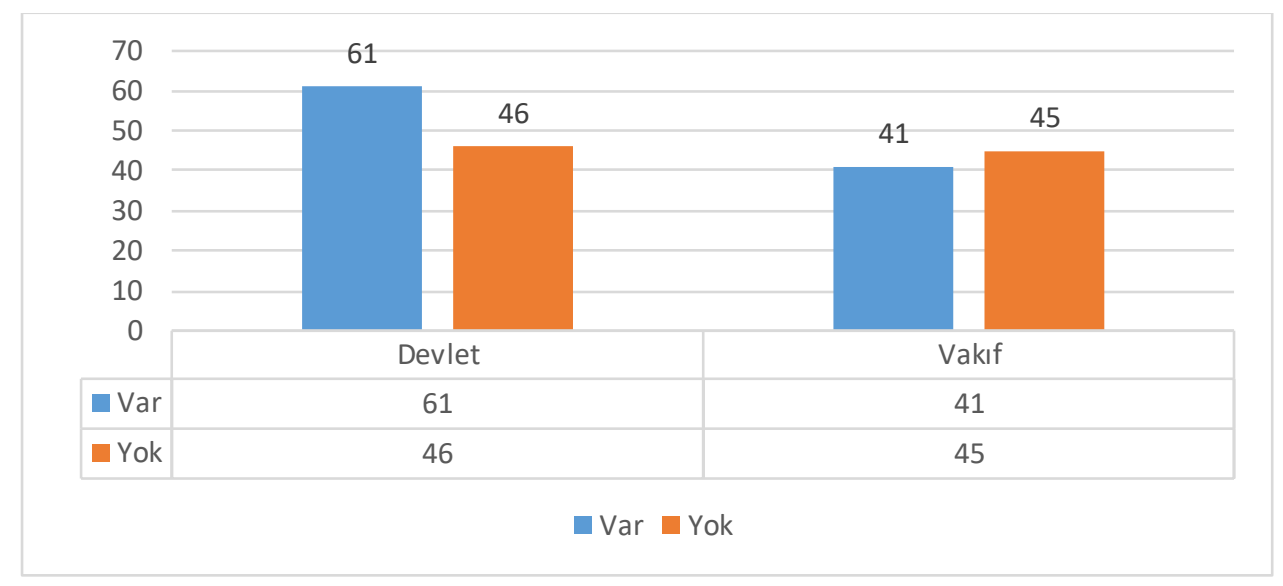

Grafik 2 incelendiğinde, 193 üniversiteden 102 üniversitenin İnternet sayfasında kalıcı bir slogana yer verdiği, 91 üniversitenin ise yer vermediği görülmektedir. Slogan kullanımının dağılımına devlet ve vakıf üniversiteleri ekseninde bakıldığında slogana yer vermeyen vakıf ve devlet üniversitelerinin neredeyse eşit bir dağılıma sahip olduğu görülmektedir. Dolayısıyla slogan tercih edip etmeme durumunda devlet ve vakıf üniversiteleri arasında anlamlı bir farklııı yoktur. 


\section{Bulgular}

\section{Sloganlarda yer alan bağdaşıklık unsurları}

Sloganlar, kelime grubu olma yahut cümle oluşturma biçimlerine göre gruplandırılmış, elde edilen veriler Grafik 3'te gösterilmiştir.

\section{Grafik 3. Sloganların söz dizimi özellikleri}

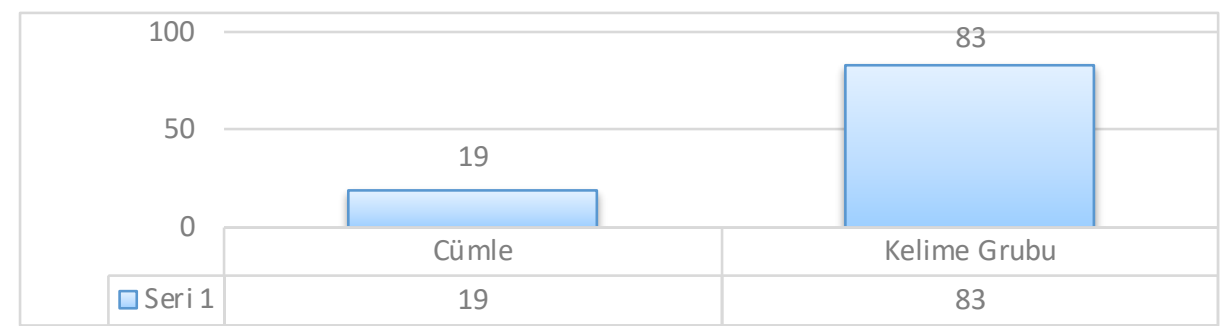

Grafik 3'te görüldüğü üzere, 83 üniversitenin sloganı kelime grubundan oluşurken; diğer 19 slogan, cümle biçimindedir. 102 üniversiteye ait sloganlar, kelime sayısı bakımından incelendiğinde en uzun sloganın 8, en kısa sloganın ise 1 kelimeden oluştuğu görülmüştür. Her bir sloganda yer alan ortalama kelime sayısı ise 4 olarak tespit edilmiştir. İlgili çalışmalar, sloganlarda bulunması gereken kelime sayısı konusunda bir ölçüt koymasa da "olabildiğince kısa" ve "akılda yer eden" ifadeleri, neredeyse tüm slogan tanımlarında yer almaktadır. Bununla birlikte, özellikle cümle biçimindeki sloganların kelime grubu biçimindeki sloganlara kıyasla daha uzun olduğunu söylemek mümkündür.

Günay (2003)'a göre tümcelerin dizilişi, oluşturucu ögelerin yinelenmesi, artgönderimler, öngönderimler, eksiltili yapılar, eylem zamanının belirlenmesi, tümceler arası bağıntı ögeleri gibi sözdizimsel ögelerin belirlenmesi, bağdaşıklık ile ilgilidir. Bu ögelerden eylem zamanı ve şahıs özelliklerini belirlemek için, cümle olarak oluşturulan üniversite sloganlarına yönelik dil bilgisel çözümlemeler Tablo 1'de verilmiştir.

Tablo 1. Cümle biçimindeki sloganların kip ve şahıs özellikleri

\begin{tabular}{|l|l|l|l|}
\hline Slogan & $\begin{array}{l}\text { Yüklem } \\
\text { Türü }\end{array}$ & Kip Özellikleri & Şahıs Özellikleri \\
\hline "Bilimin aydınlığında geleceğe yürüyoruz" & Fiil & Şimdiki Zaman & 1. Çoğul Şahıs \\
\hline Bir Geleceğin Olsun & Fiil & Emir Kipi & 3. Tekil Şahıs \\
\hline "Cumhuriyeti Seviyorum" & Fiil & Şimdiki Zaman & 1. Tekil Şahıs \\
\hline "Değişmek, dönüşmektir!" & İsim & Geniş Zaman & 3. Tekil Şahıs \\
\hline "GELECEĞi NiZE iMZAMıZı ATIYORUZ" & Fiil & Şimdiki Zaman & 1. Çoğul Şahıs \\
\hline "Gelecek Burada" & İsim & Geniş Zaman & 3. Tekil Şahıs \\
\hline "Hayata kattığınız renkleri seviyoruz" & Fiil & Şimdiki Zaman & 1. Çoğul Şahıs \\
\hline "TERCiHiNi YAP, YAŞATMAYı SEÇ" & Fiil & Emir Kipi & 2. Tekil Şahıs \\
\hline Bizler Dünyayı Değiştirebiliriz & Fiil & Yeterlilik Kipi & 1. Çoğul Şahıs \\
\hline
\end{tabular}


Üniversite Sloganlarının Bağdaşıklık Açısından İncelenmesi

\begin{tabular}{|l|l|l|l|}
\hline Değerinize Değer Katar & Fiil & Geniş Zaman & 3. Tekil Şahıs \\
\hline GAZiLi OLMAK AYRICALIKTIR & İsim & Geniş Zaman & 3. Tekil Şahıs \\
\hline Geleceğinize Yön Verin & Fiil & Emir Kipi & 2. Çoğul Şahıs \\
\hline Gelecek Burada Şekillenir... & Fiil & Geniş Zaman & 3. Tekil Şahıs \\
\hline Hayallerinizi şehrin merkezinde gerçekleştirin! & Fiil & Emir Kipi & 2. Çoğul Şahıs \\
\hline Hedefinize Bizimle Yürüyün... & Fiil & Emir Kipi & 2. Çoğul Şahıs \\
\hline Mesleğin Olacak, Geleceğin Olacak & Fiil & Gelecek Zaman & 3. Tekil Şahıs \\
\hline TEDÜ'LÜ OL! & Fiil & Emir Kipi & 2. Tekil Şahıs \\
\hline Türkiye'nin Sağıık Gücüne Güç Katıyoruz & Fiil & Şimdiki Zaman & 1. Çoğul Şahıs \\
\hline
\end{tabular}

Cümle biçimindeki sloganlar incelendiğinde sloganların zaman aralığının ağırlıklı olarak şimdiki zaman ve geniş zaman aralığına işaret ettiği görülmektedir. Etki alanının yanı sıra hatırlanabilirlik açısından da düşünüldüğünde basit zamanlı kiplerin akılda kalıcılığı artırdığı bilinmektedir.

Bağdaşıklık açısından önemli olan bir diğer unsur, mesajı ileten kişidir. 18 sloganın 5'i iberaberlik mesajıveren 1. çoğul şahıs ekini kullanırken 3'ü, söylemde "siz dili" olarak da bilinen 2. çoğul şahıs ekini kullanmıştır. 3. çoğul şahıs ekine yer veren slogan ise yoktur. Burada muhatabın hedef kitle, ürününse üniversite olduğu düşünüldüğünde 3. şahıs kullanımı gerekli görülmemektedir. Slogan dilinde yakın zamanda kullanılmaya başlanan ve ürünle özdeşleşmeyi işaret eden 1. tekil şahıs kullanımına 1 üniversitede rastlanılmıştır. "Cumhuriyeti seviyorum” biçimindeki slogan, bağdaşıklık bakımından incelendiğinde üniversite, öğrenci yahut üniversite personeli tarafından da söylenebilirliğe izin veren bir yapıya izin vererek üst yapıda yer alan tutarlıık unsurlarında anlam zenginleşmesi sağlamaktadır.

Cümle biçimindeki sloganlardan 2'si, 2. tekil şahsa işaret etmektedir. Her iki sloganın da ortak özelliği, aynı zamanda emir kipinde oluşturulmalarıdır. Burada hedef kitle ile ürün arasında emir kipi çatısı altında iletişim gerçekleşmektedir. 7 üniversitenin sloganı ise 3. tekil şahıs ekine sahiptir. Dolayısıyla nicel bakımdan ağırlık, bu şahıstadır.

Kelime grubundan oluşan sloganlar, türlerine göre sınıflandırımış ve elde edilen sonuçlar, Grafik 4'te verilmiştir. 
Grafik 4. Sloganlarıoluşturan kelime gruplarının dağıımı

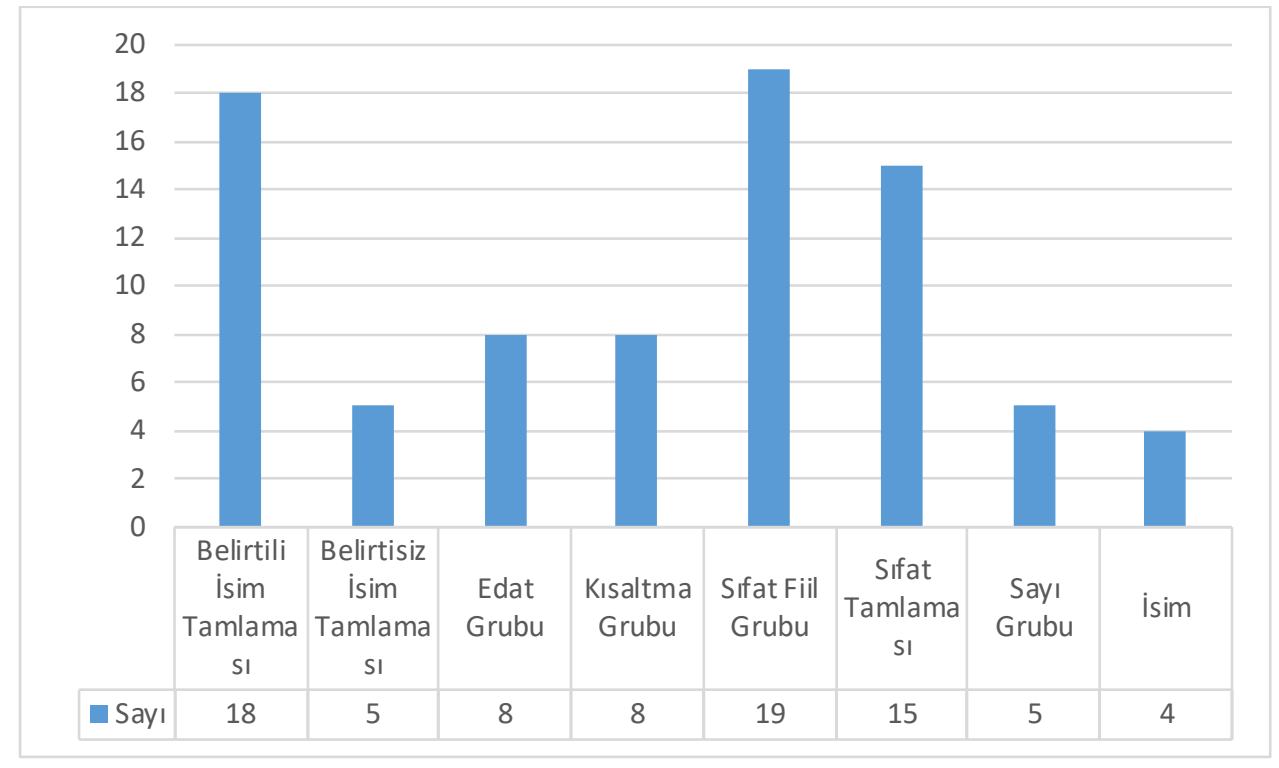

Söz dizimi/kelime grubu ekseninde sloganlar incelendiğinde 7 ayrı kelime grubu türü tespit edilmiştir. Bunların yanı sıra sadece tek biri isimden oluşan sloganlar da mevcuttur. Grafik incelendiğinde ağırlığın sıfat fiil grubunda olduğu görülmektedir. "Geleceğinize Açılan Kapı...", "Kuzeyden Parlayan Yıldız", Geleneği Gelecekle Buluşturan Üniversite, Gelişen ve Gelişstiren Üniversite ve Parlayan Yıldız sloganları, sıfat fiil gruplarına örnektir. Sıfat fiil grubu kullanımlarında sloganların üniversiteyi, bir diğer deyişle, ürünü ön plana çıkarır ve yüceltir bir ana fikirden hareket ettikleri görülmektedir.

Sıfat fiil grubundan sonra en çok tercih edilen ikinci kelime grubu, belirtili isim tamlaması grubu olmuştur. Araştırmanın Başkenti, Cumhuriyetin IIlk Üniversitesi, DEĞişiMiN ÖNCÜSÜ sloganları, bu gruba örnektir. Belirtili isim tamlaması gruplarında da sıfat fiil gruplarında olduğu gibi ürünü ön plana çıkarma amaçlanmıştır.

Kelime grupları içerisinde en çok tercih edilen üçüncü grup, sıfat tamlaması grubu olmuştur. Güler Yüzlü Bir Üniversite ve doğru meslek sağlam gelecek, bu gruba örnek oluşturan sloganlardandır.

Bu sıralamanın devamında ise edat grubu ve kısaltma grubu gelmektedir. Bilgeliğe Yolculuk..., Aydınlık Bir Geleceğe sloganları edat grubuna, Evrenseli Düşünen Yereli Gözeten, Eğitimin Ötesinde Yaşamın Iç̧inde sloganları ise kısaltma grubuna örnek teşkil etmektedir.

Belirtisiz isim tamlaması grubuna örnek olarak Bilim ve Kültür Güneşi ve Dünya Üniversitesi sloganlarını vermek mümkündür. Sayı grubundan oluşan sloganlar göz önüne alındığında (563. yıl, 61. yıl, 10 yı) bu sloganların yıl bazında sabit olmayacağı ve her yıl değişeceği görülmektedir. 4 slogan ise tek bir kelimeden (teknoversite) oluşmaktadır. 
Aynı sözcüğün aynı ya da farklı biçimde kullanılmasına yönelik kusurlu bir örnek olarak ise Özgür düşünce, özgün fikirler sloganını göstermek mümkündür. Türkçe Sözlük'te birbirlerinin eş anlamlısı olarak işaret edilen düşünce ve fikir kelimeleri, küçük yapı açısından sorun teşkil etmemekle birlikte büyük yapı açısından kusurludur.

Sloganlarda en sık rastlanan unsur, alt başlıktan üst başlığa bağlantı yahut iki farklı başlık arasında ilişki kurma biçimleri olmuştur. Alt başıktan üst başlığa doğru ilişkilendirmelere Anadolu'da Bir Dünya Üniversitesi, üst başlıktan alt başlığa doğru ilişkilendirmelere DÜNYAYA AÇILAN BILIM KAPISI, iki farklı başlık arasındaki ilişkilendirmelere Aydınlık Yarınlar İçin Kilis 7 Aralık Üniversitesi, Geleneği Gelecekle Buluşturan Üniversite, Bilginin Medeniyet ve Hoşgörüyle Buluştuğu Yer, Eğitimin 'Zirve'sinden, yaşamın zirvesine... sloganlarını örnek vermek mümkündür.

\section{Sloganlarda yer alan temalar}

Tutarlıık unsurlarını tespit edebilmek amacıyla, sloganlarda yer alan ana fikir/ana temalar tespit edilmiştir. Sloganlarda 23 ayrı temaya değinildiği görülmüştür. Bu sloganların 23 tema eksenindeki dağııımı, Grafik 5'te gösterilmiştir.

\section{Grafik 5. Sloganların tematik dağılımı}

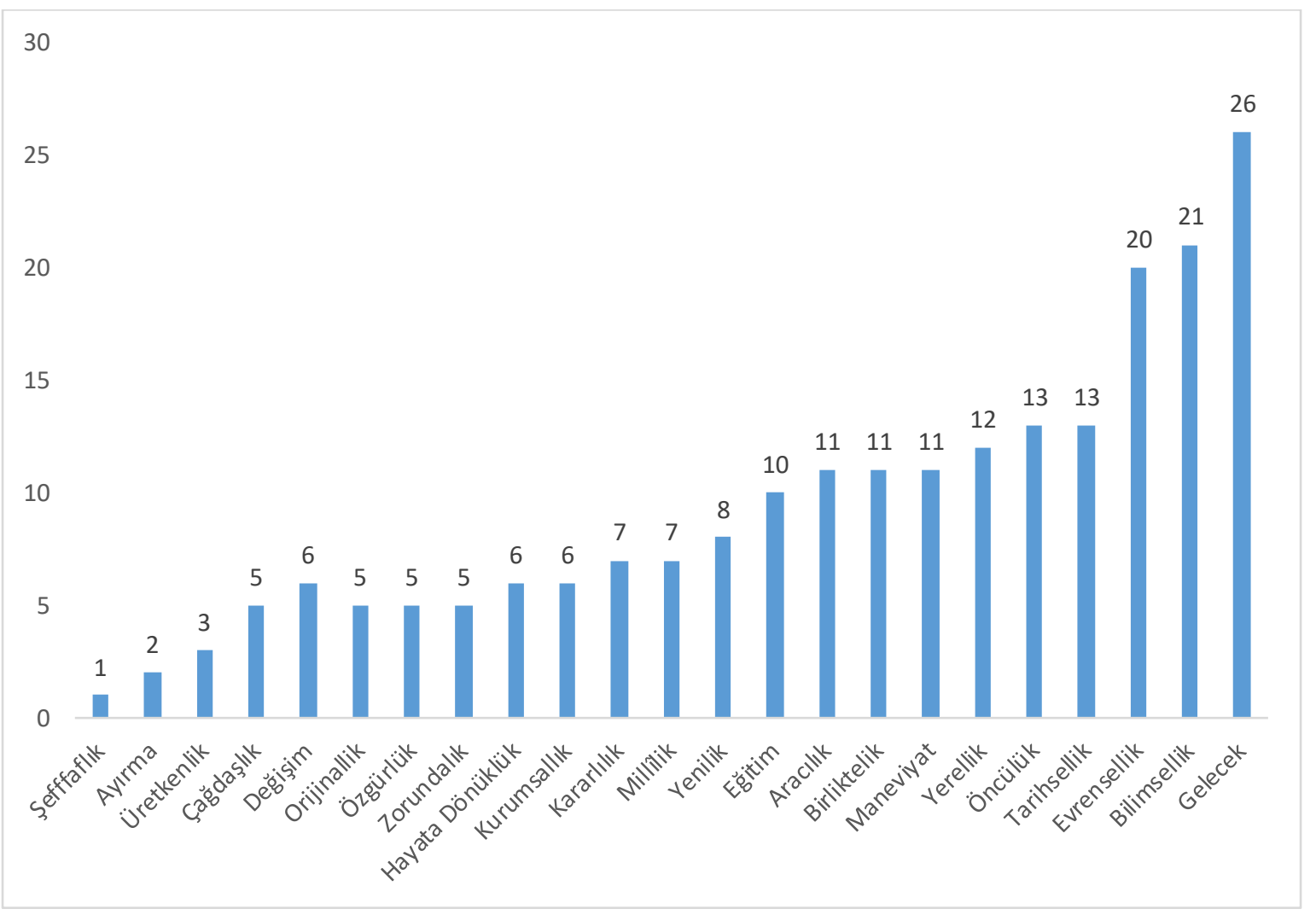

En az frekanstan başlayıp en çok frekansa sahip olan temalara dayalı üniversite sloganlarının analizini sunan grafik incelendiğinde en az yer verilen temanın Şeffaf, Katılımcı, Girişimci, Tercih Edilen 
Üniversite sloganı ile şeffaflık teması olduğu görülmektedir. Şeffaflık temasını ayırma, bir diğer deyişle ötekileştirme teması izlemektedir. GAZiLI OLMAKAYRICALIKTIR ve "Sıradan Değil, Aranan Üniversite" sloganlarındaki ana fikir, birbirine benzer biçimde öncülüğün de ötesine geçerek kendilerini diğerlerinden ayırmadır. Bu sırayı üretkenlik temasına dayalı Değer Üreten Üniversite, Değerinize Değer Katar ile Türkiye'nin Sağlık Gücüne Güç Katıyoruz sloganları takip etmektedir. Daha sonra aynı frekansa sahip olan (F: 5) çağdaşlık, orijinallik, özgürlük ve zorundalık temaları gelmektedir.

Çağdaşlık temasına örnek olarak BiLIMIN VE ÇAĞDAŞLIĞIN IŞIĞINDA BIR DÜNYA ÜNIVERSITESi sloganı, orijinallik temasına örnek olarak Üniversite eğitiminde yeni bir soluk... sloganı, özgürlük temasına örnek olarak "Bilimde Öncü, Düşüncede Özgür" sloganı, zorundalık temasına örnek olarak TEDÜ'LÜ OL! sloganını vermek mümkündür. Aynı frekansa sahip olan (F:6) olan diğer temalar değişim, hayata dönüklük ve kurumsallıktır. Değişim temasına dayalı bir örnek olarak "Değişmek, dönüşmektir!", hayata dönüklük temasına dayalı bir örnek olarak "Eğitimin Ötesinde Yaşamın İçinde", kurumsallık temasına dayalı bir örnek olarak Burası BiLGi sloganları dikkat çekmektedir.

En yüksek frekansa sahip olan (F:26) olan temanın gelecek teması olduğu görülmektedir. Gelecek temasına dayalı olan sloganlara Değişimin ve Geleceğin Adresi, doğru meslek sağlam gelecek, Türkiye'nin Geleceği, Geleceğin Üniversitesive "Aydınlık bir geleceğe" örneklerini verebiliriz. En yüksek ikinci frekansa sahip olan (F:21) tema bilimsellik iken en yüksek üçüncü frekansa sahip olan (F:20) tema evrenselliktir. Bilimsellik temasına dayalı olan sloganlar arasında Araştırmanın Başkenti, bilimin ışığında, DÜNYAYA AÇILAN BILIM KAPISI ve "Aklın Ve Bilimin Işığında Saygın Bir Üniversite.." yer almaktadır. Evrensellik temasına baktığımızda Bir Dünya Üniversitesi; Düşüncede özgür, Bilimde çağdaş, Eğitimde evrensel; IKi ÜLKE, iKi DIL, TEK ÜNIVERSITE ve Anadolu'da Bir Dünya Üniversitesi örneklerini görmekteyiz.

\section{Tartışma ve Sonuç}

Bu araştırma Türkiye'de bulunan devlet ve vakıf üniversitelerinin sloganlarını söylem çözümlemesinin bağdaşıklık unsurları ekseninde ele almıştır. 193 üniversitenin İnternet sayfalarında ve tanıtım videolarında yer alan sloganların nitel veri inceleme teknikleri ile incelendiği araştırmada 102 üniversitenin slogana sahip olduğu görülürken 91 üniversitenin sloganının olmadığı tespit edilmiştir. Sloganların büyük çoğunluğunun kelime grubu şeklinde az bir kısmının ise cümle şeklinde olduğu saptanmıştır. Bu kelime gruplarında en çok frekansa sahip unsurların sıfat fiil grubu, belirtili isim tamlaması ve sıfat tamlaması olduğu bulunmuştur. Sloganların tematik dağılımına baktığımızda ise en çok frekansa sahip olan temaların gelecek (F:26), bilimsellik (F:21) ve evrensellik (F:20) temaları olduğu görülmektedir. Şeffaflık (F:1) teması ise en az frekansa sahiptir ve bunuayırma (F:2) ve üretkenlik (F: 3) temaları takip etmektedir. 
Çalışmadan elde edilen bağdaşıklık temelli veriler öncelikli olarak ele alındığında, geniş zaman ve şimdiki zaman kullanımının yaygın kullanımına dikkat etmek gerekmektedir. Sözcük düzeyinde bağdaşıklık özelliklerine bakıldığında, Bergen ve Wheeler (2009)'in araştırmasına göre, devamlılık belirten cümleler, alımlayıcıları tanımlanmış olayların içsel işlemlerini zihinsel olarak taklit etmeye sürüklerken birleşik zamanlı yahut devam eden bir zamana işaret eden cümleler bu işlevi görmez. Bir diğer deyişle, farkı bireylere aynı yönerge, ilerleyen zamanlar ile verildiğinde eylemleri ve hareketleri anlamaları kolaylaşırken hikâye ve rivayet zamanlar bunu yapmamaktadır. Bu durum, insan zihninin geniş zaman, şimdiki zaman ve gelecek zaman kipleriyle verilen uyaranlara daha açık olduğu görüşünü desteklemektedir Oktar ve Değer'in (1999) gazete köşe yazılarını konu alan araştırmada savunulan görüşlerin haklılığını göstermek amacıyla yoğun olarak ilişkisel dizimlerin kullanıldığı saptanmış ve bu kullanımı güç ideolojisiyle ilgili olduğu belirtilmiştir. "biz" ve "siz" kullanımının dayanışma ideolojisinin bir göstergesi olduğu kabul edildiğinde, bazı üniversite sloganlarında "biz" dilinin kullanımının üniversite çıktıarını etkileyen ve bu çıktılardan etkilenen tüm paydaşlarla birliktelik duygusunu geliştirmek amaçı olduğu söylenebilir çünkü seçilen kelime ya da ögeler alıcı üzerinde etki bırakmaktadır ve üniversitelerin de slogan seçimlerinde paydaşlar üzerindeki etkilerini göz önüne aldığını söylemem mümkündür. Bazı üniversite sloganlarında geniş zaman kipine rastlamak mümkündür ve geniş zaman kullanımı kesinlik ve doğruluk ile ilişkilendirildiklerinden (Oktar \& Değer, 1999), bu zamanı sloganlarında kullanan üniversitelerin yaptıkları eylemlerde kesinlik ve doğruluk olduğunu ima ederek paydaşları üzerinde etki bıraktığını söylemek mümkündür. Bradley ve Meeds (2002), yaptıkları bir araştırmada sloganlarda edilgen yerine etken yapı kullanarak ve zarfları fiilden uzaklaştırmak yerine fiilin yanına yerleştirerek düzenleme yapmış, katılımcıların bu değişimden etkilenip etkilenmediklerini araştırmışlardır. Kohli ve arkadaşları (2007), sloganların algılanmasının bu değişimden etkilenmediğini tespit etmiş olsalar da bir kelime/kavram/sloganı listeden seçme gibi bir tanınma eyleminin basit yapılar ile daha etkili ve kolay olduğunu belirtmişlerdir. Tablo 2 tekrar hatırlandığında tüm yapıların etken çatıdan oluştuğu görülmektedir. İsimler ve logolar kolayca değiştirilemediği için slogan, bir markanın mirası ve gelişen görüntüsü arasında bir köprü görevi gören benzersiz bir aracıdır. Sloganlar kısa vadeli promosyonlarla ilgili olarak kullanılabilseler de (örneğin, olimpiyatlar gibi önemli bir durum ile bir markayı ilişkilendirmek için), çoğunlukla marka kimliği için uzun vadeli bir stratejinin bir bölümüdür (Kohli vd., 2007: 417). Bağdaşıklık açısından sorun teşkil etmeyen bu durum, izleyici/alıcıda kalıı etki bırakabilmesi bakımından üst yapıda sorun oluşturabilecektir.

Bir metindeki bütünlük içinde, daha önce ve daha sonra aynı sözcük, izlek, kavram ya da düşünce aynı ya da farklı biçimde yeniden kullanılabilir (Günay, 2003: 61). Bu artgönderim ya da öngönderimler, metinlerde bağdaşıklık unsurlarının en önemlilerindendir. "Gelecek Burada, Gelecek 
Burada Şekillenir... Burası BiLGi” sloganları, bu gönderimlerin kullanıldığı sloganlara örnek teşkil etmektedir.

Sloganlardaki tema kullanımı dikkate alındığında Öncülük temasını birliktelik ve maneviyat takip etmektedir. Bu unsurlar, Humboldt temelli üniversite sistemi için, bir diğer deyişle bilgi temelli bir üniversite için, önceliğe sahip unsurlar gibi görünmese de Readings (1996)'e göre üniversitelerin karşı karşıya kaldıkları meydan okumaların en temel ve önemlilerinden biri de toplumdakien merkezî işlevlerinden birini -yurttaş yaratma işlevini- hızla yitiriyor olmalarıdır. Dolayısıyla güven, sevgi gibi manevi unsurlar ile birliktelik vaadi, üniversitenin bir sosyal sermaye depolayıcısı olarak sorumlulukları arasındadır.

Söylem çözümlemesi niteliğindeki bu araştırma Özyıldırım’ın (2010) çalışmasıyla benzerlikler göstermektedir. Tıpkı TV reklamları gibi üniversite reklamlarının da ikna edici ve etkileyici özelliklerinin olduğunu söylemek mümkündür çünkü analiz sonucu ortaya çıkan ve en çok kullanım sıklığına sahip olan bilimsellik, evrensellik ve gelecek temalarının öğrenci ve öğretim üyeleri adaylarını olumlu yönde etkileme ve teşvik etme gücü olduğunu göstermektedir. Yapılan araştırma sonucunda üniversitelerin kullandığı sloganlarını kuruluş yeri ve amacı ile paralel olarak içinde bulundukları coğrafya ilgili izler taşıdığı görülmüştür. Bu bağlamda Kantar (2014)'ın bulguları bir anlamda sağlamlaştırılmıştır çünkü ilgili sloganlarda yerel kültür ve dil özelliklerini yansıtan ögeler kullanılmıştır. Yine Wangenge-Ouma ve Langa (2010)'ya paralel olarak, sloganların kendi amaçlarına destek sağlaması, yani üniversite değerlerini tanıtan ve eğitim kalitesini yansıtan yapılar kullanması, tanıtımlarında slogana yer veren üniversitelerin ortak özelliği olarak yorumlanabilir çükü Özyıldırım (2010)'ın da belirttiği gibi bu sloganlar aday öğrenci ya da öğretim üyesini belirli bir yönde etkileme potansiyeline sahiptir. Elde edilen bağdaşıklık ve tutarlılık bulgularından hareketle üniversitelerin belirli bir mantık çerçevesinde slogan oluşturduklarını söylemek mümkündür. Tıpkı Gonzales ve Pacheco (2012)'nun da belirttiği gibi üniversitelerin tanınmış bir üniversite düzeyine ulaşmak için belirli bir mantık içerisinde sloganlarını oluşturması gerektiği düşünülmektedir. Sloganlardaki tutarlıık unsurları dikkate alındığından en fazla yer verilen temanın gelecek, bilimsellik ve evrensellik olduğu görülmektedir. Bu oranı tarihsellik, öncülük ve yerellik takip etmektedir. Öncülük, bu temalar arasında diğerlerinden bağımsız bir öneme sahiptir. Greenwood ve Levin (2002)'e göre üniversiteler, giderek mezunlarını istihdam eden önde gelen işverenlerin değer biçtiği türden öncü bilgileri üretme faaliyetlerine katılmayan ama akademik profesyonel mevkileri dolduran öğrencileri eğitir hâle gelmektedir. Bu durum, akademi dünyası ile özel sektör arasındaki uzaklığı daha da artırmaktadır. Dolayısıyla üniversitenin öncülük görevini üstlenmesi ve sloganında bu temayı desteklemesi, üniversite ve hayat arasındaki bağlantıyı sağlamlaştıracaktır. 


\section{Üniversite Sloganlarının Bağdaşıklık Açısından İncelenmesi}

\section{Kaynaklar}

Arslan, E. (2014). Türkiye'de reklam sloganlarının gündelik dil pratikleri üzerindeki etkisinin değerlendirilmesi:

Ege Üniversitesi öğrencilerine yönelik bir araştırma. Marmara Iletişim Dergisi, 21, 57-72.

Bamberg, B. (1983). What makes a text coherent? College Composition and Communication, 34, 417-429.

Bander, R. B. (1983). American English rhetoric (3 ${ }^{\text {rd }}$ Edition): Holt, Rinehart and Winston.Beaugrande, R., \& Dressler, W. (1981). Introduction to text linguistics. London: Longman

Bergen, W., \& Wheeler, K. (2010). Grammatical aspect and mental simulation. Brain and Language, 112, 150-158.

Can, R. (2012). Ortaöğretim öğrencilerinin yazılı anlatımlarında paragraf düzeyinde bağdaşıklık ve tutarlıık. Ankara: Gazi Üniversitesi, Yayımlanmamış doktora tezi.

Coşkun, E. (2005). Illköğretim öğrencilerinin öyküleyici anlatımlarında bağdaşıklık, tutarlılık ve metin elementleri. Ankara: Gazi Üniversitesi, Yayınlanmamış doktora tezi.

Cresswell, J. W., Plano Clark, V. L., Gutmann, M. L., \& Hanson, W. E. (2003). Advanced mixed methods research designs. In A. Tashakkori \& C. Teddlie (Eds.), Handbook of mixed methods in social and behavioral research. Thousands Oaks, Calif.: Sage.

Çoban, A. (2012). Ilköğretim 7. sınıf öğrencilerinin oluşturdukları öyküleyici metinlerin bağdaşıklık ve tutarlılık ölçütlerine göre değerlendirilmesi. Kayseri: Erciyes Üniversitesi, Yayınlanmamış doktora tezi.

Demir, Ö., \& Acar, V. (2005). Sosyal bilimler sözlüğü. Ankara: Adres Yayınları.

Dörnyei, Z. (2007). Research methods in applied linguistics. Quantitative, qualitative and mixed methodologies. New York: Oxford University Press.

Duenas, G. (2000). Sosyal sermaye yaratıcıları olarak üniversiteler. Eğitimin Geleceği: Üniversitelerin ve eğitimin değişen paradigması.G. Babüroğlu (Ed.). İstanbul: Sabancı Üniversitesi Yayınları.

Ersoy, M. (2014). Türkiye'de yayınlanan 1980 sonrası reklam sloganlarında duygusal pazarlama. İstanbul: Beykent Üniversitesi, Yayınlanmamış yüksek lisans tezi.

Glaser, B. G., \& Strauss, A. L. (1980). The discovery of grounded theory: strategies for qualitative research (11 $1^{\text {th }}$ ed.). New York: Aldine Publishing Company.

Gonzales, L. D., \& Pacheco, A. (2012). Leading change with slogans: Border university in transition. Journal of Cases in Educational Leadership 15(1), 51 -65.

Günay, D. (2003). Metin bilgisi. İstanbul: Multilingual Yayınları.

Halliday, M. A. K., \& Hasan, R. (1976). Cohesion in English. London: Longmans.

Hobbs, J. R. (1979). Coherence and coreference. Cognitive Science, 3(1),67-90.

Johnson, P. (1992). Cohesion and coherence in compositions in Malay and English. RELC Journal, 23(2), 1-17.

Kantar, M. (2014). Çok uluslu şirketlerin marka adı ve slogan kullanımında standardizasyon dereceleri: Türkiye ve Orta Doğu incelemesi. Denizli: Pamukkale Üniversitesi, Yayınlanmamış doktora tezi.

Karahan, L. (2005). Türkçede söz dizimi. Ankara: Akçağ Yayınları. 
Kohli, C., Leuthesser, L., \& Suri, R. (2007). Got slogan? Guidelines for creating effective slogans. Business Horizons, 50, 415-422.

Kuo, C. (1995). Cohesion and coherence in academic writing: From lexical choice to organization. RELC Journal, 26(1), 47-62.

Lehto X., Lee G., \& Ismail, J. (2012). Measuring congruence of affective images of destinations and their slogans. International Journal of Tourism Research, 16, 250-260.

Levin, M., \& Greenwood, D. J. (2000). Üniversite-toplum Ilişkilerinin yeniden yaratılması: Akademik taylorizm. Eğitimin Geleceği: Üniversitelerin ve eğitimin değişen paradigması. G. Babüroğlu (Ed.). İstanbul: Sabancı Üniversitesi Yayınları.

Miles, M. B., \& Huberman, A. M. (1994). Qualitative data analysis. London: Sage Publication.

Oktar, L., \& Cem Değer, A. (1999). Gazete söyleminde kiplik ve işlevleri. Dilbilim Araştırmaları Dergisi.

Erişim Adresi: http://dad.boun.edu.tr/article/view/5000129401. 21 Eylül 2016 tarihinde http://dx.doi.org/10.18492/da.59005 adresinden alınmıştır.

Özyıldırım, I. (2010). Tür çözümlemesi: Türçe metin incelemeleri ve karşılaştırmalar. İstanbul: Bilgesu Yayınları.

Palmer, J. C. (1995). Coherence and cohesion in the English language classroom: The use of lexical reiteration and pronominalisation. RELC Journal, 30(2), 61-85.

Richard, J., Platt, J., \& Weber, H. (1985). Longman dictionary of applied linguistics. London: Longman.

Scheffler, I. (1961). A rejoinder on confirmation. Philosophical Studies, 12(1-2), 19-20.

Thornberg, R. (2012). Informed grounded theory. Scandinavian Journal of Educational Research, 56(3), 243-259.

Uysal, B.,\& Kayman, Y. (2014). University as a Taylorist institution and the perception of the motto: The case of Gazi University.. H. Arslan, G. Raţă, E. Kocayörük, M. A. l̇çbay (Ed.), Turkey multidisciplinary perspectives on education. UK: Cambridge Scholars Publishing.

Wangenge-Ouma, G., \& Langa, P. (2010). Universities and the mobilization of claims of excellence for competitive advantage. High Education, 59, 749-764.

Widdowson, H. G. (1983). Learning purpose and language use. Oxford: Oxford University Press.

Yılmaz, Ö. (2012). 11. sınıf öğrencilerine ait öyküleyici metinlerin bağdaşıklık ve tutarlılık açısından incelenmesi. Zonguldak: Bülent Ecevit Üniversitesi, Yayınlanmamış doktora tezi. 